\title{
Erratum to: Do Moderate Voters Weigh Candidates' Ideologies? Voters' Decision Rules in the 2010 Congressional Elections
}

\author{
James Adams ${ }^{1}$ - Erik Engstrom ${ }^{1}$ - Danielle Joesten Martin ${ }^{1}$. \\ Walter J. Stone ${ }^{1} \cdot$ Jon Rogowski ${ }^{2} \cdot$ Boris Shor $^{3}$
}

\section{Erratum to: Polit Behav \\ DOI 10.1007/s11109-016-9355-7}

In the original publication of the article, the full name of the authors are inadvertently missed out. This has been corrected with this erratum.

Danielle Joeston should be Danielle Joesten Martin.

Walt Stone should be Walter J. Stone.

The online version of the original article can be found under doi:10.1007/s11109-016-9355-7.

James Adams

jfadams@ucdavis.edu

1 Department of Political Science, UC Davis, Davis, CA 95616, USA

2 Department of Political Science, University of Washington-St. Louis, St. Louis, MO, USA

3 Department of Political Science, Georgetown University, Washington, DC, USA 